\title{
Climatic selection on body colour in Cepaea
}

\author{
Robert H. Cowie and \\ J. S. Jones
}

\author{
Department of Genetics and Biometry, University \\ College London, Wolfson House, 4 Stephenson Way, \\ London NW1 2HE, U.K.
}

\begin{abstract}
There is geographical variation in body colour in the land snails Cepaea nemoralis and $C$. hortensis along a transect of 88 samples from the north of Scotland to the Pyrenees. Paler body colour is associated with higher mean daily maximum temperature in both species. Laboratory experiments show that dark-bodied snails heat up more rapidly and reach a higher equilibrium temperature than do pale snails when exposed to radiant energy. Climatic selection favouring pale body colour in warm areas and dark body colour in cold areas is probably responsible for the association with climate.
\end{abstract}

\section{INTRODUCTION}

Most of the extensive work on the ecological genetics of Cepaea land snails has concentrated on the variation in shell colour and banding pattern. These snails also show considerable geographic variation in allozyme frequency, which has been mapped in various parts of Europe (Johnson, 1976; Jones, Selander and Schnell, 1980; Ochman, Jones and Selander, 1983 and in preparation), but which is not correlated with any obvious pattern of selective agents. It is now clear that many evolutionary forces act upon these polymorphisms (e.g., Jones, Leith and Rawlings, 1977).

Students of Cepaea have long been aware of a further mode of variation which also shows geographic differentiation: the colour of the soft body of the snails. This variation is at least partially under genetic control (Cain and Sheppard, 1952; Murray, 1963; Cain, Sheppard and King, 1968; Wolda, 1969). Its pattern of distribution has only rarely been considered (e.g., Cain and Currey, 1963) and has never been investigated on a large scale. Here we report a European survey of body colour in Cepaea nemoralis and $C$. hortensis; a survey analogous to that for shell characters (Jones, Leith and Rawlings, 1977) which showed that for C. nemoralis the proportion of yellow (i.e., pale-coloured) shells in a population is strongly correlated with mean summer temperature. Our transect extends from the north of Scotland to the Pyrenees and also includes samples from Poland and Denmark. It excludes the most northern populations of $C$. hortensis (in northern Scandinavia) and the most southern populations of $C$. nemoralis (in Spain, Italy and Yugoslavia), but covers the greater part of the climatic ranges of both species.

We describe also some experiments on the thermal relations of dark- and pale-bodied snails.

\section{METHODS}

Thirty-five samples of $C$. nemoralis and 53 of $C$. hortensis were collected during 1984; these included samples from five populations containing both species. One sample of $C$. nemoralis came from near Krakow in Poland, and a single mixedspecies sample from near Aarhus in Denmark; the remainder came from the U.K. and France (fig. 1). Habitats were classified as follows: habitat type (1) dune and marram grass, (2) cliff-top and cliffface, (3) short grass, (4) rough herbage (open and unshaded), (5) rough herbage (wood-edge). None of the samples came from within woodlands. The single Polish and Danish sites and one of the Scottish sites (samples 148, 149, 151) were not classified since habitat information was not available. Further details of sampling sites can be obtained from the authors. Whenever possible 50 adult snails were collected at each site, and in the great majority of cases were collected within an area smaller than the panmictic unit for Cepaea (approximately $30 \mathrm{~m}$ diameter for a 


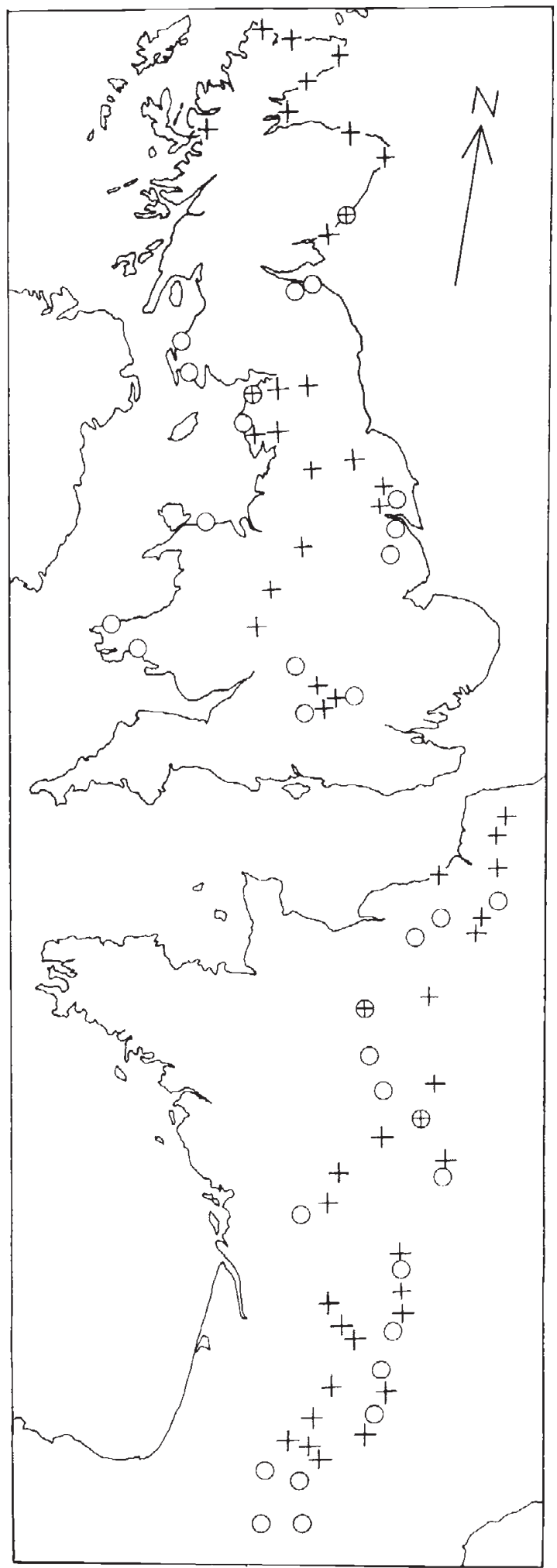

Figure 1 British and French sampling locations. Circles-C: nemoralis, crosses- $C$. hortensis, crosses within circles-mixed species samples. two-dimensional habitat, $50 \mathrm{~m}$ for a linear habitat-Lamotte, 1951; Murray, 1962). Mortality meant that the number scored from a sample was sometimes less than 50 .

Body colour was scored by matching to the coloured chips in the Munsell Book of Color (1958). Following Cain and Sheppard (1952) and Cain and Currey (1963), the colour was scored on the area between the tentacles of the extended snail. Colour matching was done in an enclosed area under standardised conditions of fluorescent light. There was only slight variation in hue; most snails were greyish, sometimes with a tinge of brown or yellow, and could be scored on pages $10 \mathrm{YR}, 2 \cdot 5 \mathrm{Y}$ and $5 \mathrm{Y}$ of the colour book. This variation in hue has been ignored and body colour matched to the range of 10 neutral shades from black (0) to white (10) to give a measure of darkness or paleness.

Jones, Leith and Rawlings (1977) plotted shell colour against mean daily temperature for July, but we have here used mean daily maximum temperature for July since this is probably of greater importance in snail thermal relations. Temperatures near the sampling locations were obtained from climatic maps of Britain (Meteorological Office, 1975) and France (Météorologie Nationale, 1974) by interpolation between the isotherms on the maps. Temperatures for Krakow and Aarhus were obtained from tables (Meteorological Office, 1967, 1972). Where necessary, the appropriate adjustment of temperature according to altitude was made.

Laboratory experiments were carried out on $C$. nemoralis to test the thermal relations of dark-and pale-bodied snails exposed to radiant heat. The snails used had their shells painted grey to remove thermal differences arising from shell colour and banding, and were drowned immediately before the experiments so that the head and foot were extended out of the shell. They were placed on a polystyrene tile in size-matched pairs of one dark snail (colour score 2, 3 or 4) and one pale snail (colour score 5 or 6 ). Ten pairs of snails were used. Fach pair was illuminated from above by a 150 watt high intensity photo-enlarger light bulb $20 \mathrm{~cm}$ above them in a room with an air temperature of $5^{\circ} \mathrm{C}$. A sheet of clear plastic was placed between the bulb and the snails to reduce convectional heating. The temperatures within the external soft parts were then recorded at one minute intervals using thermocouples inserted into each of the snails' bodies until equilibrium temperatures were reached (i.e., three consecutive readings differed by no more than $0 \cdot 1^{\circ} \mathrm{C}$ ). Humidity was kept constant during the experiments. 


\section{RESULTS}

The body colour score of individual snails varied from 2 to 7 in $C$. nemoralis, and from 2 to 8 in $C$. hortensis; a range from dark slate grey to pale creamy-yellow. Mean body colour within samples (tables 1 and 2) ranged from 3.37 to 5.94 for $C$. nemoralis and 2.48 to 6.45 for $C$. hortensis.

Body colour score was regressed on temperature by using all 88 samples without weighting according to sample size (figs. 2 and 3 ). This was legitimate despite the small size of a few samples since the sampling error associated with the mean scores of body colour was much less than the residual error about the regressions. Those few samples of less than 20 individuals are distinguished in the figures. The linear regression for C. nemoralis is:

$$
\text { body colour score }=1 \cdot 67+0 \cdot 13 T
$$

and for C. hortensis is:

$$
\text { body colour score }=0 \cdot 98+0 \cdot 14 T
$$

in which $T$ represents mean daily maximum July temperature in ${ }^{\circ} \mathrm{C}$. The slopes of these regressions are significantly different from zero $(p<0.001$ for both species), and the 95 per cent confidence limits of the regression coefficients indicate no significant difference between species in either slope or intercept ( $C$. nemoralis $-1.67 \pm 1.71$ and $0.13 \pm 0.08: C$. hortensis-0.98 \pm 1.08 and $0.14 \pm 0.05)$. There is therefore a strong tendency in both species for populations living in relatively warm places to have high frequencies of animals with pale bodies.

Most samples were taken from rough herbage (nettles, brambles, etc.) in roadside verges or ditches bordering fields; a few were taken from dunes, cliffs and open areas of short grass; but only a small number came from rough herbage at edges of woodland, and none from woodland (tables 1 and 2). Thus, our samples come from a fairly uniform set of open habitat populations, and it is not surprising that there is little relation of body colour to habitat type (figs. 2 and 3 ). The only hint of such an association is in C. hortensis, in which populations from dunes, cliffs and short grass tend to lie above the regression line of colour on temperature (fig. 3). This is not shown by C. nemoralis.

In all 10 laboratory experiments the dark snail heated up more quickly and reached a higher equilibrium temperature than the pale snail. The difference in equilibrium reached ranged from 0.13 to $1.27^{\circ} \mathrm{C}$ (table 3 ). The mean difference was $0.57^{\circ} \mathrm{C}$. Fig. 4 shows the results of a typical experiment in which the difference in equilibrium reached was approximately $0.5^{\circ} \mathrm{C}$. The variation

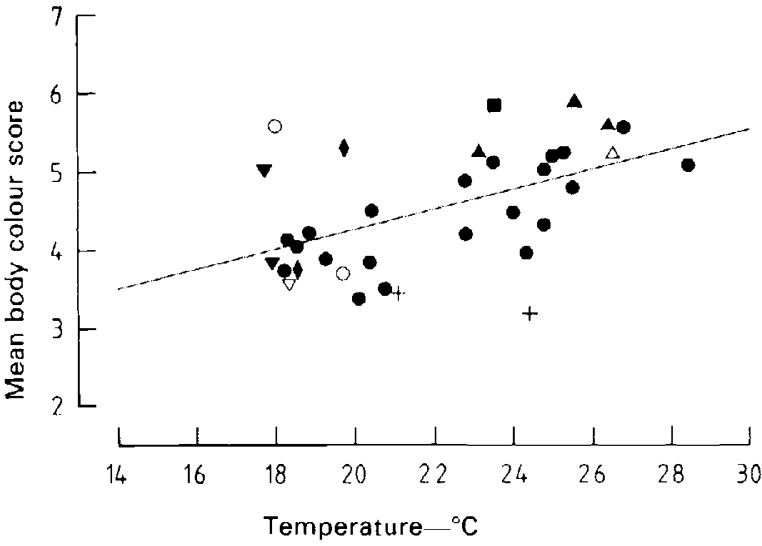

Figure 2 Regression of population mean body colour score on mean daily maximum July temperature (T) for samples of C. nemoralis. Samples are symbolised according to habitat type (see text): habitat type 1-dianonds, 2-downward-pointing triangles 3-squares, 4-circles and 5-upwardpointing triangles. Open symbols represent samples of less than 20. Crosses represent samples not classified according to habitat (both of less than 20). Sites classified as intermediate between types 4 and $5(4 / 5$ in tables 1 and 2) are symbolised as type 5 .

between these results is due partly to the greater or lesser contrast in colour between the snails used in each experiment, and to the difficulty of inserting the thermocouples in exactly the same position in each snail.

\section{DISCUSSION}

Cain and Sheppard (1952) argued that for their southern English populations of $C$. nemoralis differential visual selection by predators in open and woodland habitats was the underlying cause of geographical variation in body colour. By taking most of our samples from open habitats we have reduced the amount of variation along our transect which is explicable by visual selection and our samples are therefore not appropriate for testing this claim. Cain and Currey (1963) pointed out that Cain and Sheppard's results might also be explained, at least partially by climatic selection since insolation is greater in open habitats and pale-bodied snails may be favoured there for this reason also. The slight hint that $C$. hortensis from dunes, cliffs and short grass tend to be paler agrees with either hypothesis.

We have found extensive large-scale geographic structuring for body colour variation in Europe. This is strongly related to temperature, and is probably determined at least in part by 
Table 1 Mean and variance of body colour score, with sample size ( $n$ ), habitat type (see text) and grid reference (National Grid for U.K.; Lambert zones I, II and III for France) for populations of Cepaea nemoralis

\begin{tabular}{|c|c|c|c|c|c|}
\hline Sample & $n$ & Mean & Variance & $\begin{array}{l}\text { Habitat } \\
\text { type }\end{array}$ & Grid reference \\
\hline \multicolumn{6}{|l|}{ Britain } \\
\hline 27 & 5 & $5 \cdot 600$ & $0 \cdot 300$ & 4 & NO 775658 \\
\hline 40 & 51 & $4 \cdot 098$ & 0.570 & 4 & NY 026024 \\
\hline 41 & 60 & $4 \cdot 083$ & 0.925 & 4 & NY 020336 \\
\hline 43 & 25 & 5.000 & 0.833 & 2 & NX 092863 \\
\hline 44 & 40 & 3.725 & 0.461 & 4 & NX 202542 \\
\hline 46 & 45 & 3.889 & $1 \cdot 237$ & 4 & SE 874602 \\
\hline 47 & 49 & $3 \cdot 367$ & 0.946 & 4 & TA 063088 \\
\hline 48 & 55 & 3.855 & 0.682 & 4 & TF 128792 \\
\hline 49 & 38 & $4 \cdot 526$ & 0.851 & 4 & SU 345848 \\
\hline 50 & 32 & $3 \cdot 813$ & $1 \cdot 125$ & 2 & SM 892413 \\
\hline 51 & 51 & $5 \cdot 294$ & 0.732 & 1 & SN 326082 \\
\hline 52 & 14 & 3.714 & 0.527 & 4 & SP 123333 \\
\hline 146 & 24 & $3 \cdot 500$ & 0.696 & 4 & SP 924176 \\
\hline 147 & 45 & $4 \cdot 222$ & 0.949 & 4 & NT 270691 \\
\hline 150 & 35 & $3 \cdot 743$ & 0.608 & 1 & NT 449788 \\
\hline 152 & 9 & 3.667 & 1.000 & 2 & SH 781836 \\
\hline \multicolumn{6}{|l|}{ France } \\
\hline 102 & 41 & $4 \cdot 195$ & 0.761 & 4 & $59322382 \mathrm{I}$ \\
\hline 108 & 51 & $5 \cdot 216$ & 0.613 & 4 & 56082795 II \\
\hline 111 & 50 & $4 \cdot 820$ & $0 \cdot 396$ & 4 & 5715207611 \\
\hline 113 & 25 & $4 \cdot 480$ & 0.593 & 4 & $55450813 \mathrm{II}$ \\
\hline 116 & 8 & $5 \cdot 250$ & 0.500 & $4 / 5$ & 53123102111 \\
\hline 117 & 37 & $5 \cdot 595$ & 0.581 & 4 & 53832660 III \\
\hline 119 & 45 & $5 \cdot 089$ & 0.492 & 4 & $53152170 \mathrm{III}$ \\
\hline 122 & 47 & 5.936 & 0.322 & $4 / 5$ & 47011280111 \\
\hline 123 & 40 & $5 \cdot 275$ & 0.819 & 4 & 47250898 III \\
\hline 124 & 43 & $5 \cdot 884$ & 0.772 & 3 & 41840706 III \\
\hline 125 & 49 & $5 \cdot 612$ & 0.742 & $4 / 5$ & 41791561 III \\
\hline 134 & 37 & $5 \cdot 054$ & 0.996 & 4 & 39781279 II \\
\hline 138 & 47 & $4 \cdot 319$ & 0.961 & 4 & 49403008 II \\
\hline 139 & 40 & 3.975 & 0.692 & 4 & 48223316 II \\
\hline 140 & 43 & $5 \cdot 140$ & 0.885 & 4 & $46900980 \mathrm{I}$ \\
\hline 141 & 42 & $5 \cdot 286$ & 0.746 & 5 & 51051819 I \\
\hline 142 & 51 & 4.902 & 0.730 & 4 & $53452172 \mathrm{I}$ \\
\hline \multicolumn{6}{|l|}{ Poland } \\
\hline 148 & 5 & $3 \cdot 200$ & $0 \cdot 200$ & - & - \\
\hline \multicolumn{6}{|l|}{ Denmark } \\
\hline 149 & 9 & $3 \cdot 444$ & 1.778 & - & - \\
\hline
\end{tabular}

climatic selection acting to favour paler body colour in areas of higher temperature. Our experiments show that the thermal properties of differently coloured snails accord with this explanation, which is similar to that used by Cowie (1983) to explain variation in the colour of the soft parts of the snail Theba pisana over a large part of its range. Climatic selection on body colour may hence be analogous to that acting on shell colour (Jones, Leith and Rawlings, 1977) which favours paler shells in hotter areas because of their greater reflectivity of incident solar radiation, and darker shells in cooler places because of their greater ability to absorb radiation (Jones, 1973; Heath, 1975).

The wide scatter of points about the regressions (figs. 2 and 3) may arise from variation in other selective agents not related to the overall climatic trend, such as visual selection by predators (although variation in this has been reduced by our sampling method-see above), and perhaps because of random processes; also, the temperatures used for the regressions took no account of any microclimatic variations in thermal regime which might exist. 
Table 2 Mean and variance of body colour score, with sample size $(n)$, habitat type (see text) and grid reference (National Grid for U.K.; Lambert zones I, II and III for France) for populations of Cepaea hortensis

\begin{tabular}{|c|c|c|c|c|c|}
\hline Sample & $n$ & Mean & Variance & $\begin{array}{l}\text { Habitat } \\
\text { type }\end{array}$ & Grid reference \\
\hline \multicolumn{6}{|l|}{ Britain } \\
\hline 9 & 46 & $4 \cdot 152$ & 0.396 & 4 & SU 415850 \\
\hline 12 & 44 & $3 \cdot 705$ & 1.907 & $4 / 5$ & SU 785986 \\
\hline 13 & 41 & $3 \cdot 439$ & 0.302 & 4 & SP 447102 \\
\hline 14 & 46 & 3.935 & 0.373 & 5 & SD 897640 \\
\hline 15 & 45 & $3 \cdot 333$ & $0 \cdot 272$ & 4 & SK 150827 \\
\hline 16 & 28 & $3 \cdot 107$ & 0.099 & 4 & SJ 736173 \\
\hline 18 & 24 & $3 \cdot 208$ & 0.433 & 4 & SO 612689 \\
\hline 20 & 28 & $2 \cdot 750$ & 0.269 & 4 & SD 116937 \\
\hline 21 & 20 & $3 \cdot 450$ & 0.366 & 3 & SD 486925 \\
\hline 22 & 8 & $3 \cdot 000$ & 0.571 & 4 & NY 323492 \\
\hline 23 & 32 & $3 \cdot 594$ & 0.636 & 4 & NY 684512 \\
\hline 24 & 25 & $2 \cdot 480$ & $0 \cdot 260$ & 4 & SE 255952 \\
\hline 25 & 20 & $3 \cdot 550$ & 0.997 & 4 & SE 953426 \\
\hline 27 & 6 & $3 \cdot 333$ & 0.267 & 4 & NO 775658 \\
\hline 28 & 50 & $3 \cdot 200$ & 0.653 & 2 & NK 094355 \\
\hline 30 & 28 & $2 \cdot 500$ & 0.333 & 4 & NJ 663653 \\
\hline 31 & 39 & $4 \cdot 179$ & 0.467 & 1 & NH 872767 \\
\hline 32 & 51 & $3 \cdot 843$ & 0.455 & 2 & ND 033152 \\
\hline 33 & 15 & $3 \cdot 867$ & 0.410 & 1 & ND 343556 \\
\hline 34 & 39 & $4 \cdot 590$ & 0.511 & 4 & NC 714625 \\
\hline 35 & 22 & $4 \cdot 318$ & 0.417 & 3 & NC 393687 \\
\hline 37 & 29 & $2 \cdot 586$ & 0.323 & 4 & NG 865346 \\
\hline 43 & 50 & $3 \cdot 700$ & 0.500 & 2 & NX 092863 \\
\hline 45 & 47 & $3 \cdot 851$ & 0.477 & 4 & SE 863663 \\
\hline 151 & 7 & $4 \cdot 571$ & $0 \cdot 286$ & - & NO 682443 \\
\hline \multicolumn{6}{|l|}{ France } \\
\hline 101 & 45 & $3 \cdot 867$ & 0.482 & 4 & $59703131 \mathrm{I}$ \\
\hline 103 & 34 & $3 \cdot 912$ & 0.750 & 5 & 59002325 I \\
\hline 104 & 30 & $4 \cdot 900$ & 0.714 & 4 & 57452061 I \\
\hline 105 & 39 & $4 \cdot 128$ & 0.904 & 4 & $52831221 \mathrm{I}$ \\
\hline 107 & 45 & $4 \cdot 511$ & 0.528 & 5 & 55683130 II \\
\hline 108 & 46 & $5 \cdot 283$ & 0.341 & 4 & 56082795 II \\
\hline 110 & 32 & $5 \cdot 156$ & 0.846 & 4 & 57222156 II \\
\hline 112 & 42 & $4 \cdot 452$ & 0.888 & 4 & 55550891 II \\
\hline 114 & 32 & $4 \cdot 813$ & $1 \cdot 125$ & $4 / 5$ & 55793599 III \\
\hline 115 & 36 & $4 \cdot 028$ & 0.371 & 4 & 55263267 III \\
\hline 118 & 50 & $5 \cdot 060$ & 0.466 & 5 & 53862443 III \\
\hline 120 & 50 & 6.000 & 0.980 & 5 & 52511878 III \\
\hline 121 & 34 & $5 \cdot 000$ & 0.848 & 4 & 48391599 III \\
\hline 126 & 40 & $6 \cdot 450$ & 0.613 & $4 / 5$ & 42791857 III \\
\hline 127 & 39 & $6 \cdot 154$ & $1 \cdot 397$ & 4 & $4553 \quad 1843$ III \\
\hline 128 & 51 & $5 \cdot 647$ & $1 \cdot 273$ & $4 / 5$ & 45212125 III \\
\hline 129 & 40 & $3 \cdot 275$ & 0.256 & $4 / 5$ & 46982417 III \\
\hline 130 & 39 & $4 \cdot 256$ & 1.459 & 4 & 49502946 III \\
\hline 131 & 44 & $4 \cdot 364$ & 0.795 & 4 & 48023161 III \\
\hline 132 & 51 & $4 \cdot 588$ & $1 \cdot 127$ & 5 & 45973316 III \\
\hline 135 & 39 & $5 \cdot 051$ & 0.786 & $4 / 5$ & 43451469 II \\
\hline 136 & 48 & $4 \cdot 625$ & 0.750 & 4 & 46371906 II \\
\hline 137 & 38 & $4 \cdot 395$ & 0.732 & $4 / 5$ & 50052456 II \\
\hline 140 & 45 & $4 \cdot 711$ & 0.619 & 4 & 46900980 I \\
\hline 143 & 48 & 3.979 & 0.617 & 4 & 53422503 I \\
\hline 144 & 52 & 5.077 & $0 \cdot 386$ & 4 & 57402846 I \\
\hline 145 & 50 & $3 \cdot 640$ & 0.317 & $4 / 5$ & 57533069 I \\
\hline \multicolumn{6}{|l|}{ Denmark } \\
\hline 149 & 12 & $3 \cdot 167$ & $1 \cdot 242$ & - & - \\
\hline
\end{tabular}




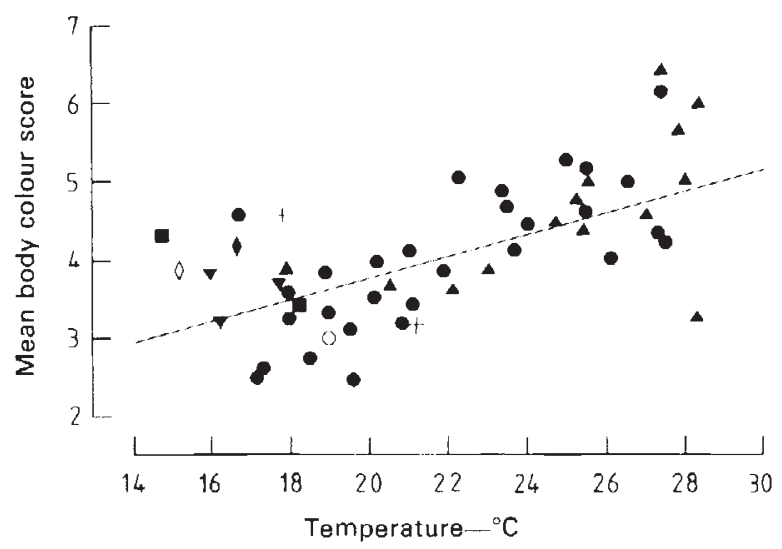

Figure 3 Regression of population mean body colour score on mean daily maximum July temperature (T) for samples of $C$. hortensis. Symbolisation as in fig. 2. Samples not classified according to habitat type (crosses) were again of less than 20 .

The mechanism of action of climatic selection on body colour is not known. High temperatures could kill dark-bodied snails (as appears to be the case for dark-shelled individuals-Richardson, 1974), and low temperatures may prevent adequate activity, feeding and growth of pale-shelled snails. Climatic selection might also act on other components of fitness such as fecundity, mating ability or developmental time.

Since snails are very vulnerable to overheating and desiccation when active, to an extent much greater than when resting and withdrawn inside their shells (Riddle, 1983), it is possible that the importance of climatic selection is greater for body colour than for shell colour and pattern. Thus body colour might show a closer relation with temperature than does shell phenotype, and the latter might be more influenced by local variations in visual selection and other factors. This might

Table 3 Equilibrium temperatures $\left({ }^{\circ} \mathrm{C}\right)$ reached (mean of last three readings) by dark and pale snails in the 10 laboratory experiments

\begin{tabular}{lll}
\hline Dark & Pale & Difference \\
\hline 13.63 & 13.07 & 0.56 \\
15.57 & 15.03 & 0.54 \\
11.63 & 10.77 & 0.86 \\
14.37 & 13.67 & 0.70 \\
15.37 & 14.63 & 0.74 \\
15.03 & 14.73 & 0.30 \\
14.77 & 14.07 & 0.17 \\
13.70 & 13.57 & 0.13 \\
15.40 & 14.13 & 1.27 \\
14.33 & 13.87 & 0.46 \\
\hline
\end{tabular}

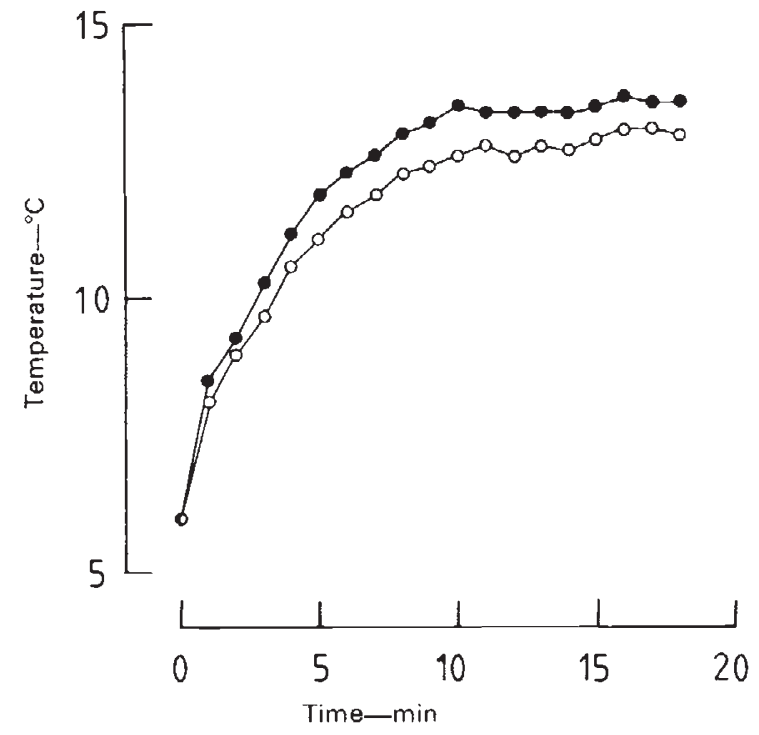

Figure 4 Body temperatures of a dark snail (solid circles) and a pale snail (open circles) exposed to the radiant light source.

explain the strength of this association between body colour and temperature, despite the relatively small numbers of samples available. In addition, Lewontin (1984) has shown theoretically that it is intrinsically more difficult to detect population differences in characters controlled at a single locus than in polygenic characters, so we would also expect trends in body colour to be more easily demonstrable than trends in the frequencies of the shell colour and pattern alleles. For this reason we have not considered large-scale geographical trends in shell colour and pattern in these samples. Such trends can only safely be interpreted if very large numbers of large samples are available (e.g., Jones, Leith and Rawlings, 1977).

This study adds to our knowledge of the ecology and evolution of thermal relations in animals, knowledge largely derived from studies of insects (e.g., reviews in Heinrich, 1981) and lizards (e.g., reviews in Gans and Pough, 1982). Body colour is well known to influence internal temperatures of small poikilotherms (e.g., Watt, 1968). It can of course also be important for camouflage, as a warning signal, for use in courtship and in species recognition. Variation in body colour in some terrestrial slugs (Arion spp.) has been suggested to be aposematic (Scharff, 1891), and dark body colour in the land snail Arianta arbustorum at high altitudes explained not only in terms of ability to warm up at low temperatures but also as a shield from ultra-violet radiation 
(Burla and Stahel, 1983). Here we have demonstrated that climatic selection influences body colour in both $C$. nemoralis and $C$. hortensis. However, there is little doubt that many other agents are operating on this system of variation and that the importance of these will differ among localities. The control of body colour in Cepaea may well be a problem with just as many solutions as is the control of the shell polymorphism.

Acknowledgements We thank S. E. R. Bailey, F. Christiansen, L. R. Noble, M. S. Povey, J. N. Rafinski and T. H. Warwick for collecting samples; S. P. Oldfield and D. W. Young for help with the extensive collecting in France; A. E. Mitchell and D. I. Johnson for assistance with the experiments.

\section{REFERENCES}

BURLA, H. AND STAHEL, W. 1983. Altitudinal variation in Arianta arbustorum (Mollusca, Pulmonata) in the Swiss Alps. Genetica, 62, 95-108.

CAIN, A. J. AND CURREY, J. D. 1963. Area effects in Cepaea. Phil. Trans. R. Soc. B, 246, 1-81.

CAIN, A. J. AND SHEPPARD, P. M. 1952. The effects of natural selection on body colour in the land snail Cepaea nemoralis. Heredity, 6, 217-231.

CAIN, A. J., SHEPPARD, P. M. AND KING, J. M. B. 1968. Studies on Cepaea I. The genetics of some morphs and varieties of Cepaea nemoralis (L.). Phil. Trans. R. Soc. B, 253, 383396.

COWIE, R. H. 1983. Variation in mantle collar colour in the land snail Theba pisana. Evidence of climatic selection? Proc. Acad. Nat. Sci. Philad., 135, 154-162.

GANS, C. AND POUGH, F. H. (eds.) 1982. Biology of the Reptilia. Vol. 12, Physiology C, Physiological Ecology. Academic Press, London.

HEATH, D. J. 1975. Colour, sunlight and internal temperatures in the land-snail Cepaea nemoralis (L.). Oecologia (Berl.), $19,29-38$.

HEINRICH, B. (ed.) 1981. Insect Thermoregulation. Wiley, New York.

JOHNSON, M. S. 1976. Allozymes and area effects in Cepaea nemoralis on the western Berkshire Downs. Heredity, 36, 105-121.

JONES, J. S. 1973. Ecological genetics and natural selection in molluscs. Science, 182, 546-552.
JONES, J. S., LEITH, B. H. AND RAWLINGS, P. 1977. Polymorphism in Cepaea: a problem with too many solutions? Ann. Rev. Ecol. Syst., 8, 109-143.

JONES, J. S., SELANDER, R. K. ANI) SCHNELL, G. D. 1980. Patterns of morphological and molecular polymorphism in the land snail Cepaea nemoralis. Biol. J. Linn. Soc., 14, 359-387.

LAMOTTE, M. 1951. Recherches sur la structure génétique des populations naturelles de Cepaea nemoralis (L.). Bull. Biol. Fr. Belg. Suppl, 35, 1 238.

LEWONTIN, R. C. 1984. Detecting population differences in quantitative characters as opposed to gene frequencies. Am. Nat., 123, 115-124.

METEOROLOGICAL OFFICE. 1967. Tables of temperature, relative humidity and precipitation for the world. Part III. Europe and the Atlantic Ocean north of $35^{\circ}$ N. H.M.S.O., London.

METEOROLOGICAL OFFICE. 1972. Tables of temperature, relative humidity, precipitation and sunshine for the world. Part III. Europe and the Azores. H.M.S.O., London.

METEOROlOGICAL OfFICE. 1975. Climatological Memorandum No. 73, Maps of mean and extreme temperature over the United Kingdom 1941-1970. Met. Office, Bracknell.

métÉorologie NAtiona.Le. 1974. Atlas climatique de la France. Ministère des Transports, Secretariat General a l'Aviation Civile, Direction de la Météorologie Nationale, Paris.

MUNSELL BOOK OF COLOR. 1958. Munsell Color Company Inc., Baltimore.

MURRAY, J. 1962. Factors affecting gene-frequencies in some populations of Cepaea. D.Phil. Thesis, University of Oxford.

MURRAY, J. 1963. The inheritance of some characters in Cepaea hortensis and Cepaea nemoralis (Gastropoda'). Genetics, 48, 605-615.

OCHMAN, H., JONES, J. S. ANI) SELANDER, R. K. 1983. Molecular area effects in Cepaea. Proc. Nat. Acad. Sci. U.S.A., 80, 4189-4193.

RICHARDSON, A. M. M. 1974. Differential climatic selection in natural populations of land snail Cepaea nemoralis. Nature, 247, 572-573.

RIDDLE, W. A. 1983. Physiological Ecology of Land Snails and Slugs. In RUSSELL-HUNTER, W. D. (ed.) The Mollusca, Vol. 6, Ecology, Academic Press, London.

SCHARFF, R. F. 1891. The slugs of Ireland. Sci. Trans. R. Soc. Dublin, 4, 513-562.

WATT, W. B. 1968. Adaptive significance of pigment polymorphism in Colias butterflies. I. Variation of melanin pigment in relation to thermoregulation. Evolution, 22, 427-458.

WOLDA, H. 1969. Genetics of polymorphism in the land snail Cepaea nemoralis. Genetica, 40, 475-502. 